\title{
The Affective Objectives in Early Foreign Language Teaching: A Scale Development Study
}

\author{
Süleyman Nihat Şad' \\ College of Education, Inonu University, Turkey \\ Oğuz Gürbüztürk² \\ College of Education, Inonu University, Turkey
}

\begin{abstract}
The main purpose of this study was to develop a valid instrument which can reliably measure the affective behaviors of young learners of English. To obtain the content and face validity of the scale, the items developed based on the review of relevant literature were assessed by an expert panel. The construct validity of the scale was tested through two independent pilot studies using exploratory (EFA) and confirmatory (CFA) factor analysis techniques. The data were obtained from 194 and $3394^{\text {th }}$ and $5^{\text {th }}$ grade students in successive studies. The analyses revealed a 4-factor structure with satisfactory model-data fit indices: $X^{2} / d f=1.371 ; R M S E A=0.033 ; R M R=0.019$; Standardized $R M R=0.044 ; G F I=0.95$; $A G F I=0.93 ; \mathrm{NNFI}=0.97 ; \mathrm{CFI}=0.98$ ]. The factors of the 17-item 3-point Likert type scale were designated as Attitudes toward learning foreign languages and English lesson, Motivation: Desire and effort to learn a foreign language, foreign language anxiety, and Attitudes toward foreigners and other cultures. These four factors together explained $53.88 \%$ of the total variance. Item-total correlations and Cronbach Alpha coefficients were estimated to test the internal consistency of the scale, and test-retest correlations were estimated to test the temporal reliability of the scale. The results showed that scale is reliable in terms of internal consistency and temporal reliability.
\end{abstract}

Keywords: Teaching foreign languages to young learners, affective features, attitude, motivation, anxiety

\footnotetext{
* This study has been produced based on the dissertation written by the first author and mentored by the second author.

${ }^{1}$ Corresponding author: Inönü University, College of Education, Campus/ Malatya-TURKEY, nihat.sad@inonu.edu.tr, Phone: +90 4223774420

Inönü University, College of Education, Campus/ Malatya-TURKEY, oguz.gurbuzturk@inonu.edu.tr.

Suggested Citation:

Şad, S. N., \& Gürbüztürk, O. (2015). The affective objectives in early foreign language teaching: A scale development study. International Journal of Academic Research in Education, 1(1), 1-15.

DOI: $10.17985 /$ ijare.15364
} 


\section{INTRODUCTION}

Today, the primary foreign language teaching has been distinguished from secondary foreign language teaching, yielding two distinct stages of instruction (Edelenbos, Johnstone \& Kubanek, 2006). The main reason for this age-based specialization is because every age group has its own characteristics and learning needs, which require to be treated with different instructional strategies (Harmer, 2007, p. 8185). Teaching a foreign language to the young learners, among these age groups, has become more of an issue around the world, especially in Europe (Brewster, Ellis \& Girard, 2004; British Council, 2003; Cameron, 2001; Doyé and Hurrell, 1997; Edelenbos et al., 2006; Ellis, 2004; Ytreberg, 1997).

There is a consensus in the relevant literature about the age of the learners who fall within the category of young language learners. Phillips (1993) defines these age group as the children aged between 5-6 (first year of formal schooling) and 11-12. Slatterly and Willis (2001) define children between 7 and 12 years of age as young language learners, and children under 7 as very young language learners. Ellis (2004) defines children between 5-10/11 as the target group of early foreign language teaching.

In Turkey, early foreign language teaching was first launched in $4^{\text {th }}$ and $5^{\text {th }}$ grades of state primary schools in 1997-1998 school year as compulsory education became 8 years (Aslan, 2008; Demirezen, 2003; Kırkgöz, 2007; Zehir Topkaya \& Küçük, 2009). Thus, a new curriculum was developed for the young learners in $4^{\text {th }}$ and $5^{\text {th }}$ grades (Zehir Topkaya \& Küçük, 2009). By 2006, the foreign language curriculum for the first and second stages of primary schools were combined and revised. The new 2006-2007 Primary English Language Teaching curriculum was prepared to address two age groups (MEB, 2006). First one was the young age group including $4^{\text {th }}$ and $5^{\text {th }}$ grades (9-12 years of age), and the second one was adolescents including 6th, 7th, and 8th grades (starting from 11-12 years of age). The curriculum defines the developmental characteristics and learning needs of both age group and stresses the necessity to plan the instruction in accordance with these characteristics and needs (MEB, 2006, p. 3-6).

In developing the foreign language teaching curriculum for the young learners, one should decide very carefully which cognitive, affective and psycho-motor behaviors young learners can and should gain considering their developmental characteristics (Agullo, 2006; Cameron, 2001; Edelenbos, et al., 2006; Tost Planet, 1997). The success of the curriculum prepared for young learners, who enjoy the age-related advantages, first depends on the compatibility of the specified objectives and instruction with the pedagogical principals regarding the age group (Agullo, 2006; Cameron, 2001; Doyé \& Hurrell, 1997; Edelenbos et al., 2006; Tost Planet, 1997; Ytreberg, 1997). "Over-ambitious or inadequately planned and resourced initiatives can frustrate parents, teachers and possibly pupils" (Edelenbos et al.., 2006, p. 27).

\section{The objectives of early foreign language learning}

The broad aims of earlier foreign language learning were identified under four items at the Council of Europe Workshop (Kuperberg, 1993, as cited in Komorowska, 1997, p. 55): a) "To develop receptive skills through listening"; b) "to develop a positive attitude toward other languages and cultures"; c) "to sensitize the child to similarities and differences of languages and cultures"; and d) "to build motivation to learn more languages". The three main goals of early foreign language teaching in Taiwan were "to cultivate students' basic communicative capacity in English", "to cultivate students' motivation for, and interest in learning English", and "to increase students' multi-cultural knowledge and awareness" (as cited in Wang, 2008, p. 4). In Austria, the fundamental objectives for primary foreign language curriculum are "to motivate for life-long language learning", "to prepare the ground for communicating in a foreign language", "to generate in children essentially positive attitudes toward other 
languages and respect for other ways of thinking and acting" (Jantscher and Landsiedler, 2000, p. 17). In Japan, the major objectives of early primary EFL curriculum is to motivate the learners and ensure that they learn English because it is interesting and fun (Brewster et al., 2004). In Croatia, it was aimed to ensure that young pupils can "communicate with people whose mother tongue is not Croatian", "learn about foreign people and their countries", and "talk about themselves and their own country" (Stokic \& Djigunovic, 2000, p. 41). Among the objectives of early foreign language teaching in Germany in early 90s included "avoidance of anxiety, and fostering motivation and intercultural openness" (Kubanek-German, $2000,65)$. In Italy, the objectives of early foreign language teaching are to foster learners' communicative competences, support mental development and help develop positive attitudes toward different cultures (Aslan, 2008). The common objectives of different foreign language teaching curricula at primary level in UK "include developing skills and positive attitudes to language learning" (Tierney \& Gallastegi, 2005, p. 50). An analysis of Primary English Teaching Curriculum (for 4, 5, 6, 7 and 8 grades) implemented in Turkey reveals that specified objectives are limited to linguistic competences, but are deprived of explicit affective objectives (MEB, 2006, p. 61, 89). The new curriculum prescribes only the linguistic and communicative competences that learners are expected to attain (Kırkgöz, 2007).

\section{The affective objectives of early foreign language teaching}

Analyzing the early foreign language teaching objectives specified by different countries, it is noticed that having the learners gain affective objectives is as important as the cognitive objective of gaining communicative competence. This is because learners usually have their first experiences about foreign language learning during the first stage of primary education and learners' first judgments and feelings about foreign language learning are formed during these very first years, which is critical in affecting their attitudes toward foreign language learning for the rest of their lives (Djigunovic, 2009; Schindler, 2006).

Considering that foreign language learning is a life-long task, "the development of a young person's motivation, skill and confidence in facing new language experience out of school comes to be of central importance" (Council of Europe, 2009, p. 5). A comprehensive review of objectives of primary foreign language teaching in different countries and relevant literature revealed that there is a consensus about integrating the following affective objectives into the early foreign language teaching:

1) To develop positive attitudes toward learning foreign languages, foreigners and their cultures in general and foreign language classes in particular (Brewster et al., 2004; Council of Europe, 2009; Edelenbos, 1997; Edelenbos et al., 2006; Ellis, 2004; Henry \& Apelgren, 2008; Komorowska, 1997; Martin, 2005; Tost Planet, 1997),

2) To motivate young learners to leer foreign languages (Brewster et al., 2004; Edelenbos, 1997; Edelenbos et al., 2006; Komorowska, 1997),

3) To reduce negative feelings such as foreign language anxiety and to ensure that learners feel themselves confident and comfortable while learning or communicating in a foreign language (Edelenbos et al., 2006; Komorowska, 1997; Oxford \& Shearin, 1994; Scott \& Ytreberg, 2001).

Attitude can be defined, in a general sense, as "an evaluative reaction to some referent or attitude object, inferred on the basis of the individual's beliefs or opinions about the referent" (Gardner, 1985, p. 9). To Gardner (1985), favorable attitudes toward foreign language learning strengthens the possibility that learner's language learning experience is pleasant and students is encouraged to continue learning it. On the other hand, learners are expected to develop positive attitudes toward foreign cultures and people as a by-product of foreign language learning process. Positive attitudes to be developed toward target language, its people and culture can enhance motivation to learn foreign language (Ellis, 2004).

The motivation to learn a foreign language can be defined as "a combination of effort plus desire to achieve the goal of learning the language plus favorable attitudes toward learning the language" 
(Gardner, 1985, p. 10). To Dörnyei (1998) "motivation provides the primary impetus to initiate learning the $L 2$ and later the driving force to sustain the long and often tedious learning process" (p. 117).

Foreign language anxiety can be defined as the "apprehension experienced by the individual in the language class or any situation in which the language is used" (Gardner \& Maclntyre, 1993, p. 159). Foreign language anxiety is a complex structure composed of "self-perceptions, beliefs, feelings, and behaviors" as a result of classroom language learning experiences during language learning process (Horwitz, Horwitz, \& Cope, 1986, p.128). One prerequisite of foreign language teaching is to create a comfortable and enjoyable environment freed from anxiety and stress (Kara, 2004)

Unless these favorable affective objectives are secured, emergent "negative emotions inhibit language production" in second language learners (Gordon, 2007, p. 75). Moreover, if the first experiences and impressions of the children about foreign language learning are unpleasant during primary school, they may develop strong negative feelings toward language learning later on (Schindler, 2006). Even, as quoted by Horwitz et al. (1986), negative feelings like anxiety may be so serious as to affect student's selection of future career.

Despite the considerable importance of affective objectives in early foreign language teaching, it seems affective objectives were not given a special attention in the foreign language curriculum for $4^{\text {th }}$ and $5^{\text {th }}$ grades launched as of 2006-2007 school year in Turkey. Moreover, there was no room for explanations about how to evaluate the learners in terms of affective gains. In this respect, it was considered to be a need to first define the affective objectives of early foreign language teaching and develop an instrument to be used to measure the learners' levels of readiness at the outset and attainment at the end in terms of affective gains.

\section{Purpose of the study}

It was aimed to develop an instrument to measure the extent to which $4^{\text {th }}$ and $5^{\text {th }}$ grade primary students have gained the affective behaviors as required by the primary foreign language learning curricula. Thanks to this instrument, it is intended to obtain data about the extent to which the relevant curriculum serves to achieve the affective objectives of primary foreign language teaching.

\section{METHOD}

\section{Design}

The study was designed based on developing a scale called "Affective Objectives of Primary Foreign Language Teaching Scale" which aims at describing the $4^{\text {th }}$ and $5^{\text {th }}$ grade primary students' levels of affective behaviors in terms of learning a foreign language.

\section{Study groups}

In developing the "Affective Objectives of Primary Foreign Language Teaching Scale", data were collected successively from the five study groups below:

1. A total of 17 participants (including 4 primary English teachers, 2 scholars from English language teaching department, and 11 scholars from educational sciences department) took part in expert panel to test the content and face validity of the instrument. 
2. A total of 10 students randomly selected from among the $4^{\text {th }}$ and $5^{\text {th }}$ classes of pilot schools were included in the study to test the clarity and intelligibility of the draft form of the scale.

3. Data obtained from 194 students (of whom 83 were $4^{\text {th }}$ grade and 111 were $5^{\text {th }}$ grade, and 95 were boys and 99 were girls) attending at the four primary schools located in Malatya city center were used for the exploratory factor analysis.

4. Data obtained from 339 students (of whom 163 were $4^{\text {th }}$ grade and 176 were $5^{\text {th }}$ grade, and 164 were boys and 175 were girls) attending at the four different primary schools located in Malatya city center were used for the confirmatory factor analysis.

5. Lastly the test-retest reliability analysis was done on the data obtained from 52 students selected from among the different classes of $4^{\text {th }}$ and $5^{\text {th }}$ grades in one of the schools involved in confirmatory factor analysis.

\section{Development of the instrument}

"Affective Objectives of Primary Foreign Language Teaching Scale" was prepared in three-point Likert format including smiley faces in accordance with sample evaluation forms in the revised primary school

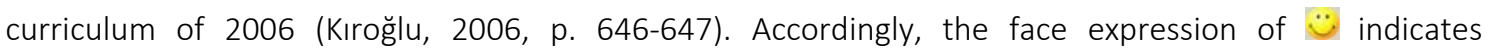

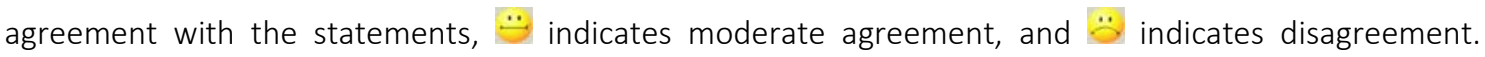
These expressions were converted to 3, 2, and 1 points to be used in statistical analysis.

The validity of the scale tested through content, face and construct validity studies. Content and face validity was ensured through expert opinion. The construct validity was tested using exploratory (EFA) and confirmatory (CFA) factor analysis methods. The internal consistency reliability was tested by estimating corrected item-total correlations, and Cronbach Alpha coefficients, while temporal consistency was tested with test-retest reliability analysis.

The data used in validity and reliability analysis were collected by the first author during the second semester of 2009-2010 academic year after necessary permissions were granted. To this end, first, the principals of the visited schools were consulted and were asked to provide a suitable place (e.g. library, laboratory, available classrooms etc.) for the students to complete the forms carefully. The students were given instructions with examples about how to complete the scale and the items were read loudly to confirm that all statements were understood well. Students were observed complete the scale in about ten minutes. The findings and comments about the scale development process have been reported below.

\section{RESULTS}

\section{Findings about the validity of the scale}

Content and face validity: In order to develop valid items in terms of content and face, first the relevant literature was reviewed. Thus, those questionnaires, scales and interview forms (Cid, Granena \& Tragant, 2009; Coleman, Galaczi \& Astruc, 2007; Demir, 2005; Dörnyei \& Csizér, 2002; Dörnyei \& Clément, 2001; Erdem, 2007; Gardner, 1985, 2004; Güreş, 2008; Heinzmann, 2009; Henry \& Apelgren, 2008; Horwitz et al., 1986; Kara, 2003; Moon, 2000; Peng \& Zhang, 2009; Wu, 2003; Yashima, 2002) previously developed to measure the affective behaviors (e.g. attitude, motivation and anxiety) concerning foreign language teaching in general and foreign language teaching to young learners in particular were analyzed. Considering the age-based characteristics of the $4^{\text {th }}$ and $5^{\text {th }}$ graders, scale items were written in brief and clear statements. The items were formed in accordance with the categories specified in the relevant literature on the affective objectives. They included a) attitudes toward learning a foreign language in general, b) attitudes toward foreign people and their cultures, c) attitudes toward foreign language classes in particular, d) motivation: the desire to learn a foreign language, e) motivation: the effort to 
learn a foreign language, and f) foreign language anxiety. Below are the items categorized accordingly in the draft form of the scale:

Table 1. Items in the draft form of the 'Affective Objectives of Primary Foreign Language Teaching Scale'

\begin{tabular}{|c|c|c|}
\hline & Categories & Items \\
\hline a) & $\begin{array}{l}\text { Attitudes } \\
\text { toward } \\
\text { learning a } \\
\text { foreign } \\
\text { language }\end{array}$ & $\begin{array}{l}\text { 1. I like learning a foreign language. } \\
\text { 2. It is fun to learn a foreign language. } \\
\text { 3. It is not necessary to learn a foreign language. }\left({ }^{*}\right) \\
\text { 4. I think learning a foreign language is waste of time. }\left({ }^{*}\right) \\
\text { 5. I think learning English is boring. }\left(^{*}\right) \\
\text { 6. I would like to learn another language beside English next year. }\end{array}$ \\
\hline b) & $\begin{array}{l}\text { Attitudes } \\
\text { toward foreign } \\
\text { people and } \\
\text { cultures }\end{array}$ & $\begin{array}{l}\text { 7. When I see a foreign tourist, I would like to talk to him/her. } \\
\text { 8. I would like to learn about the cultures of different countries. } \\
\text { 9. I would like to meet children living in different countries. } \\
\text { 10. As I learn English more, I love foreign people more. }\end{array}$ \\
\hline c) & $\begin{array}{l}\text { Attitudes } \\
\text { toward English } \\
\text { classes }\end{array}$ & $\begin{array}{l}\text { 11. My English classes are very difficult. }\left({ }^{*}\right) \\
\text { 12. Our teacher teaches English very well. } \\
\text { 13. English classes are very enjoyable. } \\
\text { 14. I love my English classes more than other classes. } \\
\text { 15. I cannot learn anything in my English classes. }\left(^{*}\right) \\
\text { 16. Our English lessons are very useful. }\end{array}$ \\
\hline d) & $\begin{array}{l}\text { Motivation: } \\
\text { Desire to learn } \\
\text { a foreign } \\
\text { language }\end{array}$ & $\begin{array}{l}\text { 17. I would like to study English even during holidays. } \\
\text { 18. My desire to learn English diminishes little by little. }\left({ }^{*}\right) \\
\text { 19. I want to learn as much English as I can. } \\
\text { 20. I want to speak English like a native speaker. } \\
\text { 21. I want to take a private course to learn better English. }\end{array}$ \\
\hline e) & $\begin{array}{l}\text { Motivation: } \\
\text { effort to learn } \\
\text { a foreign } \\
\text { language }\end{array}$ & $\begin{array}{l}\text { 22. I study English during my leisure time. } \\
\text { 23. I do not strive to overcome my deficiencies in English. }\left(^{*}\right) \\
\text { 24. I try to understand everything I hear or read in English. } \\
\text { 25. I do not feel like doing my English assignments. }\left({ }^{*}\right) \\
\text { 26. After school I revise what I have learned in English lesson. } \\
\text { 27. I am not easily distracted while studying English. } \\
\text { 28. I try to speak English to my family/friends at home or outside. }\end{array}$ \\
\hline f) & $\begin{array}{l}\text { Foreign } \\
\text { language } \\
\text { anxiety }\end{array}$ & $\begin{array}{l}\text { 29. I am afraid of being asked questions by the teacher during English lessons. } \\
\text { 30. I am afraid of making mistakes during English lessons. } \\
\text { 31. I feel uncomfortable during English lessons. } \\
\text { 32. I am afraid of speaking English during English lessons. } \\
\text { 33. I feel very relaxed during English lessons. }\left(^{*}\right) \\
\text { 34. I feel embarrassed that my teacher would ask me to volunteer answers during } \\
\text { English lessons. } \\
\text { 35. I worry that my friends would ridicule me during English lessons. }\end{array}$ \\
\hline
\end{tabular}

$\left({ }^{*}\right)$ Reversed items for each category

The 35-item draft form developed based on literature review underwent experts' assessment in terms of content, intelligibility, and suitability for the target group criteria (Yurdugül, 2005) by a panel of four primary language teachers, two scholars in ELT department, 11 scholars in Educational Sciences department. The opinions of these experts were obtained using a three-point (Unacceptable, partially 
acceptable and acceptable) nominal expert opinion form. After necessary corrections were done as per the expert views, resulting 3-point Likert type trial scale with 35 items was tested for clarity on ten $4^{\text {th }}$ and $5^{\text {th }}$ grade students selected from the primary schools included in the construct validity and reliability studies. Considering the students' views, final corrections were done on the items.

Construct validity-Exploratory factor analysis (EFA): The draft scale was administered on 260 students attending at the $4^{\text {th }}$ and $5^{\text {th }}$ grades of Hidayet, Rahmi Akıncı, Dilek and Hacı Ibrahim Işık primary schools located in province of Malatya during second semester of 2009-2010 school year. The data set obtained from the first pilot study was checked for defective/incomplete forms and outliers. The outliers were detected using standardized z scores, and cases exceeding \pm 3.00 limits were discarded (Çokluk, Şekercioğlu, \& Büyüköztürk, 2010, p. 161). Next, data from remaining 194 cases were tested for normality using skewness and kurtosis satistics, histograms, stem-leaf plots, boxplots, normal Q\&Q plots, and Kolmogorov-Smirnov test (Büyüköztürk, 2007). Except for the Kolmogorov Smirnov test results, the findings suggested that normality for each item was not violated excessively.

The suitability of the data set for factor analysis was further tested estimating Kaiser-Mayer-Olkin (KMO) and Bartlett's Test of Sphericity. The results (Kaiser Meyer Olkin $=.802$, Bartlett's Test of Sphericity= 2278.78, $d f=595, p=.000$ ) proved the factorability of the data set (Büyüköztürk, 2007; Pallant, 2001). Principal components analysis was used for the factor analysis. Also, a common orthogonal rotation technique, Varimax, was used to ensure "independence, clarity and significance in interpretation" of the extracted factors (Büyüköztürk, 2007, p. 126).

Following criteria was used for deciding about the factor structure: 1) factor loadings equal or exceed .30 (Büyüköztürk, 2007); 2) the difference between high loadings in multiple factors exceeds ".10" (Büyüköztürk, 2007; Çeçen, 2006); 3) items loaded in each factor are consistent with each other in terms meanings and content (Çeçen, 2006); 4) The eigenvalues of each component equal or exceeds 1 (Büyüköztürk, 2007; Çeçen, 2006).

As a result of the successive factor analysis, 18 items violating the criteria above (items $3,4,5,10,11,12$, $15,16,18,19,20,23,24,25,27,30,33$, and 35) were discarded from the scale. The findings of the repeated factor analysis and the obtained model, which seems to represent the theoretical model, are presented in Table 2. 
Table 2. The results of EFA for 'Affective Objectives of Primary Foreign Language Teaching Scale'

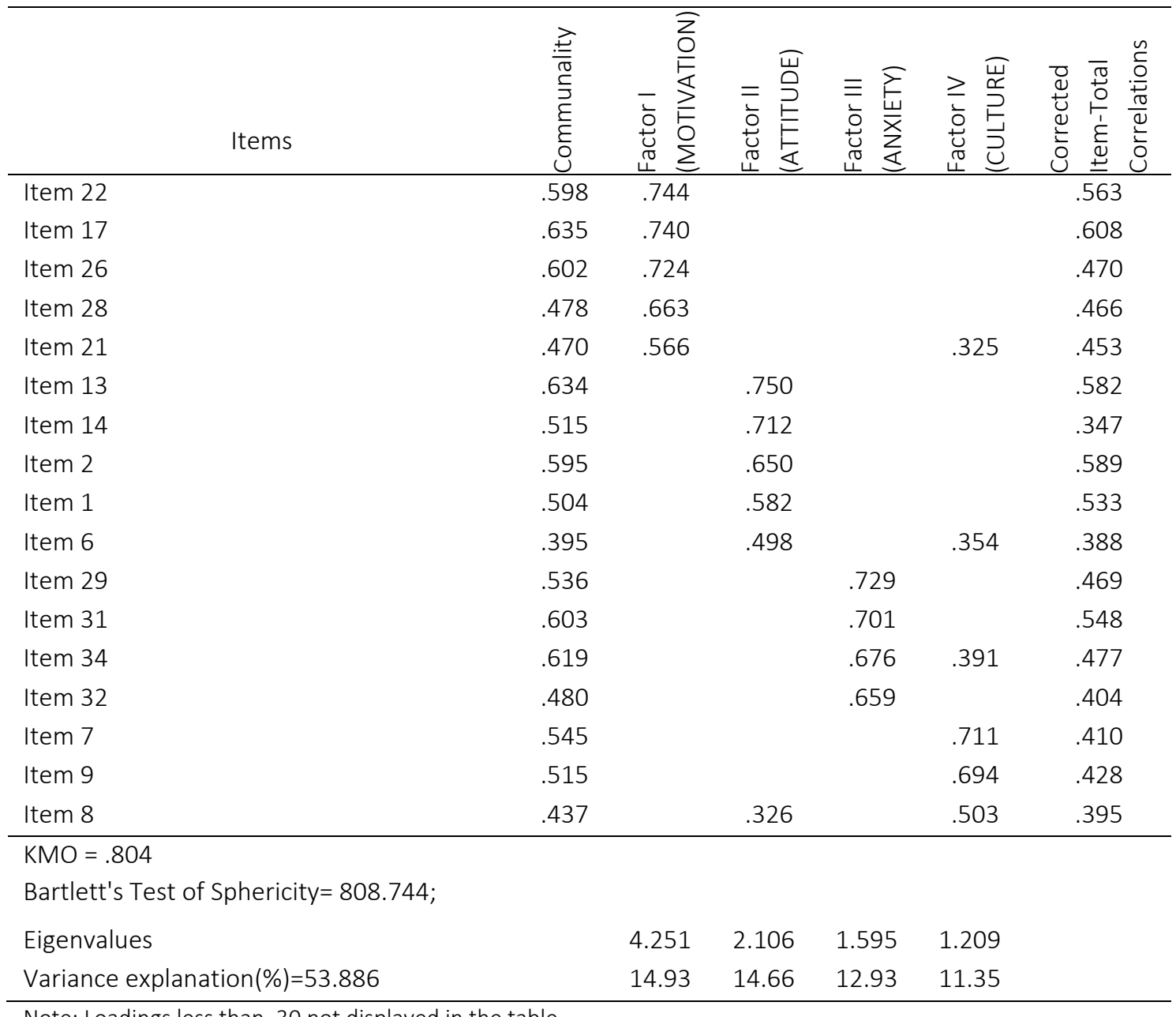

Note: Loadings less than .30 not displayed in the table

The EFA revealed 17 items loaded into four factors with loadings ranging between .498 and .750, and communalities ranging between .395 and .635 . The content of the items in each factor was examined and factors were renamed considering the initial categories in the draft form. 1) Since two (17 and 21) of the five items in the first factor were from Motivation: Desire to learn a foreign language category and three $(22,26$, and 28) were from Motivation: Effort to learn a foreign language category, first factor was named Motivation: Desire and Effort to learn a foreign language [MOTIVATION]; 2) since two (13 and 14) out of five items in the second factor were from Attitudes toward English classes category and three $(1,2$, and 6$)$ were from Attitudes toward learning a foreign language category, this factor was named Attitudes toward learning a foreign language and English classes [ATTITUDE]; 3) since all four items (29, 31, 32, and 34) in the third factor fell into foreign language anxiety category, this factor was named foreign language anxiety [ANXIETY]; and 4) finally as all three items (7, 8, and 9) in the fourth factor were about attitudes toward foreign people and cultures, this factor was called Attitudes toward foreign people and cultures [CULTURE]. The 17 items together explained 53.886\% of the total variance (MOTIVATION $=14.93 \%$; ATTITUDE=14.66\%; ANXIETY=12.93\%; and CULTURE=11.35\%).

Construct validity-Confirmatory factor analysis (CFA): In order to confirm the four-factor structure yielded in exploratory factor analysis, a confirmatory factor analysis was done using a distinct data set. Since conducting a CFA following an EFA on the same data set is not informative or even can be misleading, it is suggested to do the CFA on data from a new sample (Henson and Roberts, 2006, p. 400). Therefore, final 
form of the scale was administered on 366 students attending at the $4^{\text {th }}$ and $5^{\text {th }}$ grades of Gazi, Cahide Nebioğlu, Abdulkadir Eriş, and Barbaros primary schools located in Malatya province during the second semester of 2009-2010 school year. The data collected in this second independent pilot study was checked for defective/incomplete forms and outliers, and they were discarded from the analysis. Next, data from remaining 339 cases were tested for normality using skewness and kurtosis satistics, histograms, stem-leaf plots, boxplots, normal Q\&Q plots, and Kolmogorov-Smirnov test (Büyüköztürk, 2007). Except for the Kolmogorov Smirnov test results, the findings suggested that normality for each item was not violated excessively. The initial CFA revealed that the $t$ values for the parameters in the model were significant at ".05" level (Şimşek, 2007). Next, the goodness of fit indices for the four-factor model were tested, which yielded acceptable values. However, the modification indices produced by the program to improve the model's fit to the data (Şimşek, 2007) suggested two modifications. According to these modifications, the error variances of the $2^{\text {nd }}$ and $13^{\text {th }}$ observable variables in the ATTITUDE factor, and $26^{\text {th }}$ and $21^{\text {st }}$ observable variables of the MOTIVATION factor were associated and these associations can be added to the model. The content analysis of the $2^{\text {nd }}$ and $13^{\text {th }}$ items proved that both items have close meanings. Similarly, it was interpreted that the $21^{\text {st }}$ item expressing a desire to learn English and $26^{\text {th }}$ item expressing an effort to learn English are common in referring to a motivation to learn English outside the classroom. Thus, the errors of these item pairs were associated and added to the model. Upon these modifications, a significant decrease was observed in the $X^{2}$ value [chi-square difference with 2 degrees of freedom $=32.22(p=0.000)$ ]. Following the modifications, model was retested, which yielded the results in table 3 . The table also presents additional confirmatory factor analysis results for the data set $(n=194)$ used in EFA.

Table 3. The results of CFA for 'Affective Objectives of Primary Foreign Language Teaching Scale'

\begin{tabular}{lcccc}
\hline Goodness of fit indices & $P^{*}$ & $A^{* *}$ & EFA data set $(n=194)$ & CFA data set $(n=339)$ \\
\hline$X^{2} / \mathrm{df}$ & $\leq 2$ & $2-5$ & $156.44 / 113=1.38(\mathrm{P})$ & $152.23 / 111=1.371(\mathrm{P})$ \\
RMSEA & $\leq .05$ & $\leq .08$ & $0.045(\mathrm{P})$ & $0.033(\mathrm{P})$ \\
RMR & $\leq .05$ & $\leq .08$ & $0.020(\mathrm{P})$ & $0.019(\mathrm{P})$ \\
SRMR & $\leq .05$ & $\leq .08$ & $0.058(\mathrm{~A})$ & $0.044(\mathrm{P})$ \\
GFI & $\geq .95$ & $.90-.95$ & $0.91(\mathrm{~A})$ & $0.95(\mathrm{P})$ \\
AGFI & $\geq .95$ & $.90-.95$ & 0.88 & $0.93(\mathrm{~A})$ \\
NNFI & $\geq .95$ & $.90-.95$ & $0.92(\mathrm{~A})$ & $0.97(\mathrm{P})$ \\
CFI & $\geq .95$ & $.90-.95$ & $0.94(\mathrm{~A})$ & $0.98(\mathrm{P})$ \\
\hline
\end{tabular}

* Perfect, ${ }^{* *}$ Acceptable goodness of fit indices (Brown, 2006; Çokluk et al., 2010; Şimşek, 2007)

The goodness of fit statistics estimated for the data set from new sample $(n=339)$ were perfect for the 4factor structure of the tested scale $\left(\mathrm{X}^{2} / \mathrm{df}=1.371, \mathrm{RMSEA}=.033, \mathrm{RMR}=.019\right.$, Standardized $\mathrm{RMR}=.044$, $\mathrm{GFI}=.95, \mathrm{NNFI}=.97$, and $\mathrm{CFI}=.98$ ) except for the acceptable statistic of AGFI (.93). The standardized factor loadings, $\mathrm{R}^{2}$ and $t$ values for the observed variables are presented in Table 4. Accordingly, standardized loadings for the items ranged between 0.38 and 0.89 , error variances ranged between 0,86 and 0,21. The $t$ values for the parameters in the model were significant at the .05 level. Also the DFA results for the EFA data set $(n=194)$ yielded Perfect $\left(X^{2} / d f=1.38\right.$; RMSEA=0.045; RMR=0.020) and Acceptable values (SRMR= 0.058; $\mathrm{GFI}=0.91 ; \mathrm{NNFI}=0.92 ; \mathrm{CFI}=0.94)$, except for AGFI (0.88). Based on these findings, the goodness of fit indices for the four-factor model of the scale can be said to be confirmed, and the tested model fits to the data well. The items involved in the final form of the scale are given in the annex (see Annex 1) Also the ready to use form of the scale is provided in Turkish in Annex 2. 
Table 4. Standardized factor loadings, $R^{2}$ and $t$ values

\begin{tabular}{ccccc}
\hline Factor & Item & Standardized loadings & $R^{2}$ & $t$ \\
\hline \multirow{2}{*}{ ATTITUDE } & 1 & 0,57 & 0,32 & 9,53 \\
& 2 & 0,6 & 0,36 & 9,77 \\
& 6 & 0,47 & 0,22 & 7,69 \\
MOTIVATION & 13 & 0,55 & 0,30 & 8,76 \\
& 14 & 0,38 & 0,14 & 6,07 \\
\hline ANXIETY & 17 & 0,66 & 0,44 & 12,18 \\
& 21 & 0,61 & 0,37 & 10,55 \\
& 22 & 0,69 & 0,48 & 12,68 \\
& 26 & 0,58 & 0,34 & 9,86 \\
& 28 & 0,48 & 0,23 & 8,41 \\
\hline & 29 & 0,85 & 0,72 & 18,65 \\
& 31 & 0,89 & 0,79 & 20,08 \\
& 32 & 0,77 & 0,59 & 16,24 \\
& 34 & 0,8 & 0,64 & 17,18 \\
\hline
\end{tabular}

\section{Findings about the reliability of the scale}

The internal consistency of the scale items was tested through item-total correlations and Cronbach Alpha coefficients, and the temporal reliability was tested using test-retest analysis.

Corrected item-total correlations: Corrected item-total correlations for the items in each factor were estimated, which were found to range between .347 and .608 (see Table 2). Pallant (2001) states that corrected item-total correlation coefficients below .30 is low and indicate item is not measuring what the scale is measuring. "Positive and high item-total correlations indicate items exemplifies similar behaviors and the test has high internal consistency" (Büyüköztürk, 2007, p. 171).

Cronbach Alpha internal consistency coefficients: The Cronbach alpha coefficients were estimated $\alpha=.743$ for Motivation: Desire and effort to learn a foreign language factor, $\alpha=.706$ for Attitudes toward learning foreign languages and English lesson factor, $\alpha=.689$ for Foreign language anxiety factor, and finally $\alpha=$ .603 for Attitudes toward foreigners and other cultures factor. Considering that reliability coefficients around .70 are adequate (Kline, 2011, p. 70), all factors other than the CULTURE can be said to meet this criteria.

Test-retest reliability: A total of 60 students attending the $4^{\text {th }}$ and $5^{\text {th }}$ grades of one of the schools involved in the second pilot study were selected and administered the scale in two-week-intervals for the test-retest analysis. Yet, due to students' unattendance and defective or incomplete forms, only data from 52 students were included in the analysis. As a result, the repeated measures were compared using Pearson correlation analysis, which yielded high correlations ( $r=.913$ for ATTITUDE; $r=.897$ for MOTIVATION, r=.922 for ANXIETY; and $r=.896$ for CULTURE) suggesting favorable temporal reliability. 


\section{CONCLUSION}

This study aimed to define the affective objectives of early foreign language teaching and develop a valid instrument to be used to measure the extent to which young learners possess these affective behaviors. According to the four-factor structure of the scale developed as a result of the validity studies, these affective behaviors can be defined as motivation: desire and effort to learn a foreign language, attitudes toward learning a foreign language and English classes; foreign language anxiety, and attitudes toward foreign people and cultures. This four-factor model obtained in the exploratory factor analysis was confirmed through confirmatory factor analysis done on data from an independent group. The reliability analysis was done by estimating corrected item-total correlations, Cronbach Alpha coefficients, and testretest correlation coefficients. The results of reliability analysis suggested that the scale items are adequately reliable in terms of internal consistency and has temporal reliability, i.e. give consistent results in repeated measures. Consequently, validity and reliability studies proved adequate proofs in favor of the factorial structure and reliability of Affective Objectives of Primary Foreign Language Teaching Scale. The scale can be used to measure the extent to which young learners, $4^{\text {th }}$ and $5^{\text {th }}$ graders in the present context, possess the affective features of primary EFL.

The minimum and maximum scores possibly obtained from the ATTITUDE factor are 5 and 15, respectively. Higher scores mean that young learner has positive attitudes toward learning a foreign language in general and their English classes in particular, while lower scores mean less positive attitudes. The minimum and maximum scores possibly obtained from the MOTIVATION factor are 5 and 15, respectively. Higher scores mean that learners desire and effort more to learn a foreign language, while lower scores mean they desire and effort less. The minimum and maximum scores possibly obtained from the ANXIETY factor are 4 and 12, respectively, and all items include negative statements. Higher scores mean that learners have high foreign language anxiety, while lower scores means he/she has less foreign language anxiety. Finally, the minimum and maximum scores possibly obtained from the CULTURE factor are 3 and 9, respectively. Higher scores indicate that young learners have positive attitudes toward foreign people and their cultures, while lower scores mean less positive attitudes.

Learners' first judgments and feelings about foreign language learning are formed during the early years, which is critical in affecting their attitudes toward foreign language learning for the rest of their lives (Djigunovic, 2009; Schindler, 2006). If the first experiences and impressions of the children about foreign language learning are unpleasant during these early years, they may develop negative affective and cognitive outcomes (Gordon, 2007; Schindler, 2006). Since the affective objectives in early foreign language teaching is of considerable importance, it is believed that the affective behaviors scale developed herein can serve as a valid, reliable, and useful instrument to evaluate the young learners' foreign language curricula.

\section{References}

Agullo, G. L. (2006). Overcoming age-related differences. ELT Journal, 60(4), 365-373.

Aslan, N. (2008). Dünyada erken yaşta yabancı dil öğretimi uygulamaları ve Türkiye'deki durum. Çukurova Eğitim Fakültesi Dergisi, 35(3), 1-9.

Brewster, J., Ellis, G., \& Girard, D. (2004). The primary English teacher's guide (New Edition). England: Pearson Education Limited.

British Council (2003). Worldwide survey of primary ELT. Retrieved on 12.07.2009 http://www.britcoun.org.uk/english/eyl/index.htm

Brown, T. A. (2006). Confirmatory factor analysis for applied research. New York\&London: Guilford Press. Büyüköztürk, Ş. (2007). Sosyal bilimler için veri analizi el kitabı ( $7^{\text {th }}$ edition). Ankara: PegemA Yayıncılık. 
Cameron, L. (2001). Teaching languages to young learners. UK: Cambridge University Press.

Cid, E., Granena, G, \& Tragant, E. (2009). Constructing and validating the foreign language attitudes and goals survey (FLAGS). System, 37, 496-513

Coleman, J.A., Galaczi, Á., \& Astruc, L. (2007). Motivation of UK school pupils toward foreign languages: A large-scale survey at key stage 3. Language Learning Journal, 35(2), 245-281.

Council of Europe (2009). Common European framework of reference for languages: Learning, teaching, assessment $\left(10^{\text {th }}\right.$ edition). Cambridge: Cambridge University Press.

Çeçen, A. R. (2006). Duyguları yönetme becerileri ölçeğinin geliştirilmesi: Geçerlik ve güvenirlik çalışmaları. Türk Psikolojik Danışma ve Rehberlik Dergisi, 3(26), 101-113.

Çokluk, Ö., Şekercioğlu, G. ve Büyüköztürk, ş. (2010). Sosyal bilimler için çok değişkenli istatistik: Spss ve Lisrel yygulamaları. Ankara: PegemA Akademi

Demirezen, M. (2003). Yabancı dil ve anadil öğreniminde kritik dönemler. Dil Dergisi, 118, 5-15.

Demir, B. (2005). An investigation into effects of motivational factors and attitudes of primary school students on learning English as a foreign language. Unpublished master thesis, Çanakkale Onsekiz Mart University, Çanakkale.

Djigunovic, J.M. (2009). Impact of learning conditions on young FL learners' motivation. Marianne Nikolov (Ed.), Early learning of modern foreign languages: Processes and outcomes (pp.75-89). Bristol, UK: Multilingual Matters Ltd.

Doyé, P. \& Hurrell, A. (Eds). (1997). Foreign language learning in primary schools. Strasbourg: The Council of Europe.

Dörnyei, Z. (1998). Motivation in second and foreign language learning. Language Teaching, 31, 117-135.

Dörnyei, Z. \& Clément, R. (2001). Motivational characteristics of learning different target languages: Results of a nationwide survey. Z. Dörnyei \& R. Schmidt (Eds), Motivation and second language acquisition (pp. 399-432). Honolulu, HI: University of Hawaii Press.

Dörnyei, Z. \& Csizér, K. (2002). Some dynamics of language attitudes and motivation: Results of a longitudinal nationwide survey. Applied Linguistics, 23, 421-462.

Edelenbos, P., Johnstone, R. \& Kubanek, A. (2006). The main pedagogical principles underlying the teaching of languages to very young learners. European Commission, Final Report of the EAC 89/04, Lot 1 study http://ec.europa.eu/education/policies/lang/doc/young en.pdf

Edelenbos, P. (1997). Evaluation and assessment. P. Doyé \& A. Hurrell (Eds), Foreign language learning in primary schools (pp. 63-76). Strasbourg: the Council of Europe.

Ellis, G. (2004). Developing intercultural competence with children in the English language class. Tresholds, 1, 14-17.

Erdem, D. (2007). Ingilizce dersine yönelik bir tutum ölçeği geliştirme çalışması. Eğitim AraştırmalarıEurasian Journal of Educational Research, 28, 45-54.

Gardner, R.C. (1985). Social psychology and second language learning: The role of attitudes and motivation. London: Edward Arnold.

Gardner, R.C. (2004). Attitude/motivation test battery: International AMTB research project (English version). The University of Western Ontario, Canada. http://publish.uwo.ca/ gardner/docs/englishamtb.pdf

Gardner, R. C. \& Maclntyre, P. D. (1993). On the measurement of affective variables in second language learning. Language Learning, 43, 157-194

Gordon, T. (2007). Teaching young children a second language. USA: Praeger Publisher.

Güreş, G. (2008). Kubaşık okuma yazma dinleme ve konuşma tekniğinin ilköğretim dördüncü sınıf öğrencilerinin akademik başarılarına ve ingilizce dersine ilişkin tutumlarına etkisi. Unpublished master thesis, Adnan Menderes University, Aydın.

Harmer, J. (2007). The practice of English language teaching (4. Baskı) Harlow: Pearson Longman Limited. 
Heinzmann, S. (2009). "Girls are better at language learning than boys": Do stereotypic beliefs about language learning contribute to girls' higher motivation to learn English in primary school? Bulletin VALS-ASLA, 89, 19-36.

Henry, A. \& Apelgren, A.M. (2008). Young learners and multilingualism: A study of learner attitudes before and after the introduction of a second foreign language to the curriculum. System, 36, 607623.

Henson, R.K. \& Roberts, J.K. (2006). Use of exploratory factor analysis in published research: Common errors and some comment on improved practice. Educational and Psychological Measurement, 66, 393-416.

Horwitz, E. K., Horwitz, M. B. \& Cope, J. (1986). Foreign language classroom anxiety. Modern Language Journal, 70, 125-32.

Jantscher, E., \& Landsiedler, I. (2000) Foreign language education at Austrian primary schools: An overview. Marianne Nikolov \& Helena Curtain (Eds), An early start: Young learners and modern languages in Europe and beyond (pp. 13-27). Strasbourg: Council of Europe.

Kara, A. (2003). Duyuşsal boyut ağırlıklı bir programın öğrencilerin duyuşsal gelişimine ve akademik başarısına etkisi. Unpublished doctoral thesis, Fırat University, Elazığ.

Kara, Ş. (2004). Ana dil edinimi ve erken yaşta yabancı dil öğretimi. Uludağ Üniversitesi Eğitim Fakültesi Dergisi, 17(2), 295-314

Kırkgöz, Y. (2007). English language teaching in Turkey: Policy changes and their implementations. RELC Journal, 38, 216-228.

Kıroğlu, K. (2006). Yeni ilköğretim programları 1-5. sınıflar. Ankara: PegemA Yayıncılık.

Kline, R. B. (2011). Principles and practice of structural equation modeling ( $3^{\text {rd }}$ ed.). New York London: The Guilford Press.

Komorowska, H. (1997). Organisation, integration and continuity. P. Doyé \& A. Hurrell (Eds.), Foreign language learning in primary schools (pp. 51-62). Strasbourg: the Council of Europe.

Kubanek-German, A. (2000). Early language programmes in Germany. Marianne Nikolov \& Helena Curtain (Editörler) An early start: Young learners and modern languages in Europe and beyond (pp. 59-70). Strasbourg: Council of Europe.

Martin, C. (2005). Modern foreign languages at primary school: a three-pronged approach? Language Learning Journal, 22(1), 5-10.

MEB (2006). Illköğretim Ingilizce dersi (4, 5, 6, 7 ve 8. sınıflar) öğretim programı. Ankara: Milli Eğitim Bakanlığı Talim ve Terbiye Kurulu Başkanlığı.

Moon, J. (2000). Children learning English. Oxford: Macmillan Heinemann

Oxford, R. \& Shearin, J. (1994). Language learning motivation: expanding the theoretical framework. The Modern Language Journal, 78(1), 12-28.

Pallant, J. (2001). SPSS Survival Manual: A step by step guide to data analysis using SPSS for Windows (Versions 10 and 11). Philadelphia: Open University Press.

Peng, J. \& Zhang, L. (2009). An eye on target language use in elementary English classrooms in China. Marianne Nikolov (Ed), Early learning of modern foreign languages: Processes and outcomes (pp. 212-228). Bristol, UK: Multilingual Matters Ltd.

Phillips S. (1993). Young learners. Oxford: Oxford University Press

Stokic, L. \& Djigunovic, J.M. (2000). Early Foreign Language Education in Croatia. M. Nikolov \& H. Curtain (Eds), An early start: Young learners and modern languages in Europe and beyond (pp. 41-50). Strasbourg: Council of Europe.

Scott, W. A. \& Ytreberg, L.H. (2001). Teaching English to children (14 ${ }^{\text {th }}$ edition). New York: Longman.

Schindler, A. (2006). Channeling children's energy through vocabulary activities. English Teaching Forum, 44(2), 8-12.

Slatterly, M. \& Willis, J. (2001). English for primary teachers. Hong Kong: Oxford University Press. 
Şimşek, Ö. F. (2007). Yapısal eşitlik modellemesine giriş: Temel ilkeler ve LISREL uygulamaları. Ankara: Ekinoks Yayıncılık.

Tierney, D. \& Gallastegi, L. (2005). Where are we going with primary foreign languages? Language Learning Journal, 31(1), 47-54.

Tost Planet, M. A. (1997). Objectives and contents. P. Doyé \& A. Hurrell (Eds), Foreign language learning in primary schools (pp. 15-24). Strasbourg: The Council of Europe

Wang, Wei-Pei (2008). Teaching English to young learners in Taiwan: Issues relating to teaching, teacher education, teaching materials and teacher perspectives. Unpublished doctoral thesis, University of Waikato, Tayvan

Wu, X. (2003). Intrinsic motivation and young language learners: The impact of the classroom environment. System, 31(4), 501- 517

Yashima, T. (2002). Willingness to communicate in a second language: The Japanese EFL context. The Modern Language Journal, 86, 54-56

Ytreberg, L. (1997). Methods. P. Doyé \& A. Hurrell (Editörler), Foreign language learning in primary schools (pp. 25-34). Strasbourg: The Council of Europe.

Yurdugül, H. (2005, 28-30 Sept.). Ölçek geliştirme çalışmalarında kapsam geçerliği için kapsam geçerlik indekslerinin kullanılması. XIV. Ulusal Eğitim Bilimleri Kongresi, Pamukkale Üniversitesi Eğitim Fakültesi, Denizli.

Zehir Topkaya, E. \& Küçük, Ö. (2009). An evaluation of $4^{\text {th }}$ and $5^{\text {th }}$ grade English language teaching program. Ilköğretim Online-Elementary Education Online, 9(1), 52-65.

Annex 1. Factors and items in the final form of the scale (translated into Turkish for international readers)

Attitudes toward learning a foreign language and English classes [ATTITUDES]

Item 1- I like learning a foreign language.

Item 2 - It is fun to learn a foreign language.

Item 6- I would like to learn another language beside English next year.

Item 13- English classes are very enjoyable.

Item 14- I love my English classes more than other classes.

Motivation: desire and effort to learn a foreign language [MOTIVATION]

Item 17- I would like to study English even during holidays.

Item 21- I want to take a private course to learn better English.

Item 22- I study English during my leisure time.

Item 26- After school I revise what I have learned in English lesson.

Item 28- I try to speak English to my family/friends at home or outside.

Foreign language anxiety [ANXIETY]

Item 29- I am afraid of being asked questions by the teacher during English lessons.

Item 31- I feel uncomfortable during English lessons.

Item 32- I am afraid of speaking English during English lessons.

Item 34- I feel embarrassed that my teacher would ask me to volunteer answers during English lessons.

Attitudes toward foreign people and cultures [CULTURE]

Item 7- When I see a foreign tourist, I would like to talk to him/her.

Item 8- I would like to learn about the cultures of different countries.

Item 9- I would like to meet children living in different countries. 
Annex 2. Ready to use form of the scale in Turkish

\section{Sevgili öğrencimiz,}

Bu ölçek sizlerin yabancı dil derslerinizle ilgili görüșlerinizi öğrenmek için hazırlanmıștır. Ölçeğe vereceğiniz cevaplar tamamen gizli kalacaktır. Ölçekteki soruların doğıu ya da yanlış cevapları yoktur. Bu ölçek dersinizin ya da ödevinizin bir parçası değildir. Katılımınız için şimdiden çok teşekkür ederim.

Süleyman Nihat ŞAD, İnönü Üniversitesi, Eğitim Fakültesi

\section{KİSISSEL BİLGİLER}

Lütfen aşağıdaki sorularla ilgili uygun cevapları kutuların içerisine işaretleyiniz (X).
1. Smifinız :
4. Sinif
5. Sinif
2. Cinsiyetiniz:
$\mathrm{K} 1 \mathrm{z}$
Erkek

3. Anne-babanız İngilizce derslerinize ne sıklıkla yardım ediyor?
Hiçbir zaman
Bazen
Her zaman

\section{II. ÇOCUKLARA YABANCI DİL ÖĞRETIMININ DUYUŞSAL HEDEFLERİ ÖLÇEĞİ}

Așağıdaki soruları dikkatle okuyarak yüz ifadelerinin anlamlarına göre kutucuklara $\mathrm{X}$ işareti koyunuz:

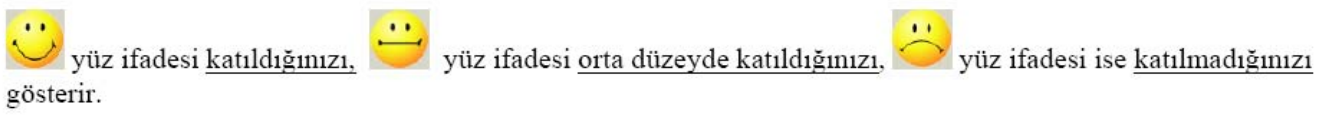

1. Yabancı bir dil öğrenmeyi seviyorum.

2. Tatillerde bile canım İngilizce çalışmak ister.

3. Gelecek yıl İngilizcenin yanında başka bir yabancı dil daha öğrenmek isterim.

4. Yabancı bir turist gördüğüumde onunla konuşmak isterim.

5. Farklı ülkelerin kültürlerini ögrenmek isterim

6. Boş zamanlarımda İngilizce çalışırım.

7. İngilizce derslerinde İngilizce konuşmaktan korkarım.

8. Okuldan sonra İngilizce dersinde öğrendiklerimi tekrarlarım.

9. İngilizce derslerini diğer derslerden daha çok seviyorum.

10. İngilizce derslerinde kendimi huzursuz hissederim.

11. Daha iyi İngilizce öğrenmek için özel kursa gitmek istiyorum.

12. Yabancı bir dil öğrenmek çok zevklidir.

13. Evde veya sokakta ailemle/arkadaşlarımla İngilizce konuşmaya çalıșırım.

14. İngilizce dersinde ögretmenin bana soru sormasından korkarım.

15. İngilizce derslerimiz çok eğlenceli.

16. Farklı ülkelerde yaşayan çocuklarla tanışmak isterim.

17. İngilizce derslerinde öğretmen beni derse kaldıracak diye çekinirim. 